\title{
Secularism before the Strasbourg Court: Abstract Constitutional Principles as a Basis for Limiting Rights
}

Ronan McCrea*

Key Words: Secularism, Fundamental Rights, Freedom of Religion, European Court of Human Rights, Neutrality, Islam, Symbolic Harm.

\section{Abstract}

The justification for the restrictions on religion inherent in secularism is the subject of lively debate in constitutional and political theory. In Ebrahimian v France the Strasbourg Court was required to assess whether the European Convention on Human Rights can accommodate a secularism whose aims and justifications go beyond the protection of the rights of others and include abstract goals such as upholding the religious neutrality of the state.

The resulting judgment highlights both the inability of rights to provide an adequate account of the relationship between religion and the state and how the text of the Convention struggles to give adequate weight to constitutional principles whose justification arises from sources other than the protection of fundamental rights.

I suggest that the Court was correct to reaffirm its stance that secularism and strict neutrality can be in harmony with the values of the Convention. However, it needs to be more clear about the reasons for this stance and to be vigilant in its protection of private autonomy so that the use of abstract principles to restrict religious expression does not give excessive latitude to states to restrict individual autonomy and minority rights.

\section{Introduction}

The French system of regulating the relationship between religion and the state has been before the Strasbourg Court (ECtHR) on several occasions. ${ }^{1}$ Applicants from France and elsewhere have had little success in challenging rules restricting religious expression in schools and universities, ${ }^{2}$ imposed in the name of secularism, and the Court has clearly stated that state secularism is, in principle, consistent with the values of the European Convention on Human Rights (ECHR). ${ }^{3} \ln$ Ebrahimian $\mathrm{v}$ France $^{4}$ the Court was faced with a challenge to restrictions on religious expression in the broader public service, a context where concerns about respect for parental autonomy and proselytism in the education system which can underpin restrictions in the educational context, do not apply.

\footnotetext{
* Senior Lecturer, Faculty of Laws, University College London, ronan.mccrea@ucl.ac.uk. I would like to thank an anonymous reviewer for their helpful comments.

${ }^{1}$ S.A.S. v France [2014] ECHR 695, Dogru v France [2008] ECHR 1579, Pichon and Sajous v France, Admissibility Decision, [2001] ECHR 898.

${ }^{2}$ Dogru v France (ibid), Dahlab v Switzerland, Admissibility Decision [2001] ECHR 899, Şahin v Turkey [2004] ECHR 299.

${ }^{3}$ Refah Partisi v Turkey [2003] ECHR 87 at [114].

${ }^{4}$ [2015] ECHR 1041. The majority judgment is in French and all translations are my own. The dissenting and partially-dissenting opinions are in English.
} 
The arguments put forward by the French authorities in favour of the restriction of religious expression in the public service as a whole forced the European Court of Human Rights to address the justifications

for secularism in broad and abstract terms. This required the Court to enter into the complex question of the ECHR's ability to accommodate a secularism whose aims and justifications go beyond the protection of the fundamental rights of others and focus on more abstract goals such as state neutrality and avoiding religious competition for state power, issues that have become increasingly controversial amongst political and constitutional theorists. The resulting judgment, and the evasiveness of the majority as to the degree to which the imposition of a duty of religious neutrality on state employees can be justified by the text of Article 9 of the Convention, highlights the dilemmas faced by rights-focused courts in accommodating broad constitutional principles whose justification arises from sources other than the protection of fundamental rights.

This article suggests that, while the overall result of this case was correct, the Court must be more upfront in future about the fact that it is drawing on extra-textual sources in its assessment of the legitimacy of constitutional principles, such as secularism, that aim to defuse salient and abiding cleavages within societies. In addition, it shows that duties of religious-neutrality in state contexts raise complex issues in relation to the proportionality of rules that seek to prevent symbolic harms and require vigilant policing of the boundary between state and non-state contexts in order to ensure that promotion of state secularism does not become unduly limiting of individual religious freedom.

\section{Facts}

Ms. Ebrahimian, worked for 15 months as a temporary social assistant in the psychiatric ward of a public hospital in the Paris region. In December 2000, her contract was not renewed as she had refused to remove the Islamic headscarf that she had been wearing at work. Her employers justified this decision on the basis that the headscarf constituted a display of her religious convictions which was incompatible with her status as a public servant, adding later that patients had complained about working with an employee wearing religious attire. The French courts held that the hospital's decision was justified in the light of the French state's secularity ('laïcité') and the consequent obligation on those working in the public service to adhere to religious neutrality when carrying out their functions.

Ms. Ebrahimian challenged this decision before the ECtHR arguing that the refusal to renew her contract constituted a violation of her right to freedom of thought, conscience and religion protected by Article 9 of the ECHR. She alleged that the decision to restrict her freedom of religion in this way lacked a sufficiently clear legal basis and was neither proportionate nor taken in pursuit of a legitimate goal as there was no evidence that her work had been affected. Ms. Ebrahimian's challenge was rejected by six votes to one.

\section{Clarity of Legal Basis}

Although the duty of public servants in France to adhere to religious neutrality at work is now clear, it was less so when Ms. Ebrahimian's contract was terminated. Nevertheless, the majority found that the decision to terminate the Applicant's employment did have a sufficiently clear legal basis. It cited 
the fact that secularism has been enshrined in French law since 1905 and appears in Article 1 of the Constitution. In addition, it noted that since the 1950s, the Conseil d'Etat had confirmed that a 'strict duty of neutrality' applied to those working for the state while the Constitutional Council has underlined the principle of neutrality as a fundamental principle of the public service. ${ }^{5}$ However, the Court acknowledged that when the Applicant was first employed, this jurisprudence was not sufficiently clear for her to have been able to foresee that her expression of her religious convictions and identity would be subject to restrictions at work. In the Court's view, it was only when the Conseil d'Etat issued an opinion on religious symbols in the public service in May 2000 (six months before her contract was not renewed) that it was sufficiently clear to the Applicant that she was required to remove her headscarf while at work. ${ }^{6}$

Judge O'Leary sharply questioned whether a court ruling, months after the applicant had been employed, could be seen to have provided the level of certainty and accessibility required by Court's case law, arguing that 'the majority judgment could be read as assessing the requirement of lawfulness not with reference to the law as it stood then but with reference to the law as it stands now, following 15 years of a wide and undoubtedly sensitive debate in French society. ${ }^{77}$ Allowing victory for the Applicant on this fact-sensitive point may have been politically astute as it would have allowed the Court to counter arguments that it has been unsympathetic to religious minorities while at the same time avoiding questioning the norms of the French system of state secularism more widely but the majority did not take this option.

\section{A Mix of Abstract and Concrete Reasons for Restrictions of Religious Expression}

Having found that the restriction was in accordance with law, the majority noted the wide margin of appreciation that applies in relation to norms around the relationship of religion and state in Europe. ${ }^{8}$ It then offered two sets of reasons why the restriction was also legitimate and proportionate. One set of reasons was relatively concrete while the other focused more on abstract constitutional principles.

Unfortunately, the Court was not entirely clear as to when it was relying on the abstract claim and when it was relying on the more concrete impact on the rights of those coming into contact with Ms. Ebrahimian at work. In a key section, ${ }^{9}$ it noted that a restriction of religious expression in a context of vulnerability of users of public services could be seen as pursuing the legitimate goal of protecting the rights and freedoms of others in that it sought to preserve respect for the beliefs of patients and users of public services and to ensure that they benefited from equal treatment without distinction as to their religion. ${ }^{10}$ However, the same paragraph goes on to say that the Court 'equally recalls that the safeguarding of the principle of secularism constitutes an objective that is in conformity with the values underlying the Convention' concluding that 'in these conditions [the prohibition on the Applicant wearing her headscarf at work] pursued the objective of protection of the rights and

\footnotetext{
${ }^{5}$ ibid at [50].

${ }^{6}$ ibid at [51].

${ }^{7}$ ibid, partially-dissenting opinion of Judge O'Leary.

${ }^{8} \mathrm{n} 4$ above at [56].

${ }^{9}$ ibid at [53].

${ }^{10}$ ibid.
} 
freedoms of others, ${ }^{11}$ thus implying that defence of secularism in the abstract was equally a legitimate goal for the purposes of the Convention and could fall within the concept of defence of the rights of others.

The Court buttressed this conclusion by reference to a line of cases where it had previously upheld limitations imposed in the name of secularism on religious expression in state contexts. It noted its decisions in Şahin v Turkey, ${ }_{12}^{12}$ Dahlab v Switzerland ${ }^{13}$ and Kurtulmus $\vee$ Turkey ${ }^{14}$ upholding restrictions on the wearing of a headscarf by a university student, school teacher and university lecturer respectively. It stressed that in Kurtulmus, Strasbourg had concluded that 'the prohibition on the wearing of the veil was justified by imperatives linked to the principles of neutrality of the public service. $^{15}$

In addition, the Court noted that its finding of a violation in the case of Ahmet Arslan v Turkey (where conviction for wearing religious uniforms in the street after a religious event was found to violate Article 9) had been partly on the basis that the Applicants in that case were in no way 'representatives of the state exercising public functions [who were not therefore] subject, by reason of their official status, to an obligation of discretion in relation to the public expression of their religious convictions' ${ }^{16}$

Thus, the Court concluded that it had already admitted 'that States could invoke the principles of secularism and state neutrality to justify restrictions on the wearing of religious signs by civil servants [....] it is their status as public agents that distinguishes them from ordinary citizens' ${ }^{17}$

The majority was conscious that the obligation of neutrality it was recognizing was strict but held that it was one that comes from 'the traditional relationship upheld by the principle of the secular nature of the State and freedom of conscience as set out in Article 1 of the [French] Constitution.' It was not for the Court, it concluded, 'to assess [the French model] as such'. Rather it was for administrative judges in France 'to verify that the administration does not do disproportionate damage to the freedom of conscience of public servants when the neutrality of the State is invoked. ${ }^{18}$ These judges, the Court concluded, had followed the French ideas of the public service and the ostentatious character of the headscarf to conclude, having taken account of the impact of her clothing on the carrying out of her functions, that the wearing of a religious sign was a breach of the Applicant's duty of neutrality justifying the failure to renew her contract. ${ }^{19}$

\section{Abstract Secularism and the Text of the Convention}

There are several noteworthy elements of this reasoning. As Brems notes, the Court's statement that it was not for it to assess the French system 'as such' would involve a dangerous degree of

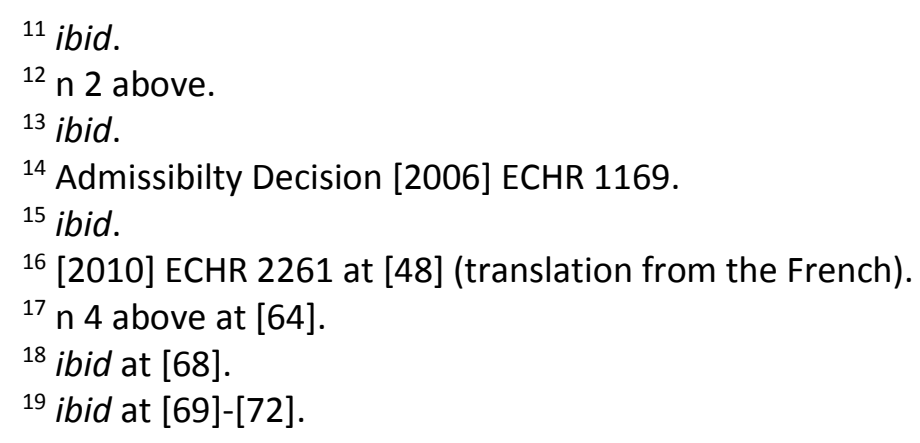


circularity. As she puts it, the applicant could be refused a contract renewal solely on account of her headgear, 'because this is the way in which France organizes secularism, and the Court should not question this French system as such. ${ }^{20}$

However, when one reads the reasons given by the Court, it is clear that it does assess the legitimacy of the French system of state secularism 'as such'. It states explicitly that it stands by the Court's assessment in earlier cases that the principle of secularism is one that is in conformity with the values underlying the Convention. ${ }^{21}$ Nonetheless, the Court seems reluctant to be entirely clear about what this assessment entails. Although it notes that it has consistently approved of secularism in general (and restrictive measures to protect it) as being in line with the values of the Convention, it seems unsure how to justify this conclusion with regard to the text of the Convention.

This is because allowing the constitutional principle of secularism per se (rather than individual instances of secularist policies preventing concrete harm to individuals such as vulnerable patients) runs into textual difficulties. As Judge O'Leary pointed out, the list of grounds justifying restrictions on freedom of religion in Article 9(2) of the Convention is exhaustive. These grounds, namely 'the interests of public safety, [...] the protection of public order, health or morals, or the protection of the rights and freedoms of others' 22 , do not provide any immediately obvious grounds for a policy of strict neutrality that is not linked to the prevention of a concrete harm to another individual.

The Court's discussion of the legitimacy of the goal pursued by the restriction of the Applicant's religious freedom in paragraph 53 attempts to get around this by collapsing the discussion of the concrete reason (the impact on vulnerable patients) and that of the abstract reason, into one. Judge O'Leary picks up on this weakness. The judgment, she notes, combines 'a fairly concrete assessment of proportionality based on the particular functions exercised by the applicant [...] [and] the context in which those functions were carried out [...]' with 'a much more abstract assessment of proportionality, rooted in the very abstract nature of the principles of neutrality and secularism' ${ }^{23}$

Judge O'Leary supported the finding of no violation based on the concrete reasons offered in relation to the Applicant's work and the context it was carried out (i.e. the vulnerability of psychiatric patients) but was critical of the Court's acceptance of the more abstract reason arguing that 'the abstract nature of the principles relied on to defeat the right under Article 9, tended also to render abstract this assessment' ${ }^{24}$ This, she said, was in tension with the stress laid by the Court in Eweida and Others $v$ United Kingdom on the need to provide 'evidence of any real encroachment on the interests of others'. ${ }^{25}$ The majority, she suggested, had failed to engage in the kind of careful examination of limitations on rights required by the Grand Chamber when 'Member States rely on

${ }^{20}$ E. Brems 'Ebrahimian v France: Headscarf Ban Upheld for the Entire Public Sector' 27 November 2015, Available at: http://strasbourgobservers.com/2015/11/27/ebrahimian-v-france-headscarfban-upheld-for-entire-public-sector/ last accessed 2 February 2015.

${ }^{21} \mathrm{n} 9$ above.

${ }^{22} \mathrm{n} 4$ above, partially dissenting opinion of Judge O'Leary.

23 ibid.

24 ibid.

25 ibid. 
flexible notions, principles and ideas to justify interferences with the freedom to manifest one's religion'. ${ }^{26}$

\section{Problems with Rights-Based Defences of Secularism}

The points raised by Judge O'Leary reflect important contemporary debates in political and constitutional theory in relation to the justification for the secular state, and highlight the degree to which the Strasbourg Court faces serious problems in ensuring that its case law can accommodate constitutional principles that can be of vital importance but which are not directly related to issues of fundamental rights.

The concrete and abstract defenses offered by the French authorities reflect two different views on what best justifies the principle of state secularism. Justifying restrictions on religious expression in state contexts with reference to the impact on the rights of others that such expression may involve, sees the duty of religious neutrality as necessary to avoid either coercing citizens to follow a faith or violating the equal status of religious minorities who may feel excluded by apparent endorsement of a faith other than their own.

The alternative view is that secularism and the duty of religious neutrality arises not from the need to protect fundamental rights ${ }^{27}$ but from the need for a religiously-diverse population to share state institutions. On this view, religion is a phenomenon particularly likely to lead to intractable political conflict. Accordingly the state must be strictly religiously neutral in order to avoid religiouslymotivated political conflict. This approach involves distinguishing between the private sphere, where individuals can express whatever religious views they please, and the state sphere where the right to express one's faith must be restricted in order to uphold the principle of religious neutrality. On this analysis, the problem with religious expression by a state employee is not that such expression violates the rights of those using state services. Instead, at work religious expression by civil servants is problematic because it undermines the idea of the religious neutrality of the state and may thus lead to attempts by religions to achieve symbolic prominence in state institutions. In addition, if those working for the state are seen as religiously partisan, this may lead to a reduction in the ability of the state to hold the allegiance of religious diverse population and may bring an increased risk of destructive religious contestation for state power.

The rights-based view of secularism has been prominent amongst American defenders of separation of church and state in recent times. Dworkin suggested that state endorsement of any particular faith (including symbolic endorsement) involved a failure to show equal concern for all citizens and therefore was a violation of the right of each individual to equal respect. ${ }^{28}$ Sager and Eisgruber argue that symbolic endorsement of a faith by the state is a disparagement to those who are of a different

\footnotetext{
${ }^{26}$ ibid, quoting S.A.S. v France, above $\mathrm{n} 1$ at [122].

${ }^{27}$ It should be noted that, even if secularism is not justified by the need to protect individual rights, given the patriarchal and illiberal nature of the mainstream teachings of many faiths, restricting religious influence over law may have the effect of protecting key fundamental rights.

${ }^{28}$ R. Dworkin, Religion without God, (Cambridge MA: Harvard University Press, 2013).
} 
faith ${ }^{29}$ while Nussbaum bases the state's duty of symbolic neutrality on the basis that those of other faiths will suffer from a sense of exclusion. ${ }^{30}$

However, rights-based justifications struggle to provide adequate support for requirements that impose a strict symbolic neutrality either on the state or those who work for it. As Laborde has pointed out, liberal states endorse, symbolically or otherwise, a range of controversial views. ${ }^{31} \mathrm{~A}$ monarchist will be offended by the symbols of the French state just as a republican will be offended by the symbols of the United Kingdom. Liberal states also endorse ideas such as democracy and racial and sexual equality that are rejected by some people.

It is unclear what fundamental right is violated by state endorsement of a particular religious belief. ${ }^{32}$ There is no recognized human right not to hear particular kinds of argument in political life or not to see particular symbols in state contexts. This point is made indirectly in the dissent of Judge Gaetano which criticizes the 'false (and,[...] very dangerous) premise [...] that the users of public services cannot be guaranteed an impartial service if the public official serving them manifests in the slightest way his or her religious affiliation'. ${ }^{33}$ There is no reason to think that the mere fact of a display of a religious symbol necessarily deprives an individual of an impartial service. A social welfare official may dispense welfare payments cheerfully and pleasantly to all while wearing a headscarf or crucifix. Indeed, if equal service provision is all that matters, a judge who deals fairly with all cases that come before her while wearing a cross or badge of her preferred political party will not have violated the rights of any individual.

If secularism can restrict religious freedom only to the extent necessary to protect individuals from concrete harm to their fundamental rights, then only very limited forms of secularism can be permitted. Indeed, the limited nature of the secularism that is required to protect fundamental rights is reflected in the wider case law of the Strasbourg Court when it has been faced with claims on the part of individuals that a failure of the state to adhere to secularist neutrality has violated their fundamental rights. In cases such as Buscarini v San Marino ${ }^{34}$ and Lautsi $\mathrm{Italy}{ }^{35}$ (challenges to a mandatory religious oath for parliamentary deputies and to the presence of a crucifix on the walls of Italian state schools) the Court has required applicants to show oppression, not a mere lack of neutrality, to establish a violation of the Convention. ${ }^{36}$ Thus, forcing deputies to recite a religious

\footnotetext{
${ }^{29}$ C. Eisgruber and L. Sager, Religious Freedom and the Constitution (Cambridge MA: Harvard University Press, 2007).

${ }^{30}$ M. Nussbaum Political Emotions: Why Love Matters for Justice (Cambridge MA: Harvard University Press 2013) 5-7.

${ }^{31}$ C. Laborde, 'Religious Freedom without God' (2014) (94)(4) Boston University Law Review 1255 at 1266-68.

${ }^{32}$ R. McCrea, 'Rights, Recourse to the Courts and the Relationship between Religion, Law and State in Europe and the United States' EUI Working Papers RSCAS 2016/09, Robert Schuman Centre for Advanced Studies, European University Institute. See also, R. McCrea 'The Consequences of Disaggregation and the Impossibility of a Third Way' in A. Bardon and C. Laborde (eds) Religion in Liberal Political Philosophy (Oxford and New York: Oxford University Press, 2016, forthcoming).

${ }^{33} \mathrm{n} 4$ above, dissenting opinion of Judge De Gaetano.

34 [1999] ECHR 7.

35 [2011] ECHR 2412.

${ }^{36}$ See I. Leigh and R. Adhar, 'Post-Secularism and the European Court of Human Rights: Or How God Never Really Went Away' (2012) 75 MLR 1064.
} 
oath (Buscarini) was a violation, the continuation of the tradition of the presence of the 'passive symbol' on the wall of classrooms in a school system found to be generally pluralist and tolerant was not (Lautsi).

\section{Secularism as a Constitutional Choice and the ECHR}

The Strasbourg Court therefore has a problem when it is faced with states seeking to uphold secular systems. If fundamental rights can only justify limited forms of secularism, this raises the issue of how the Court is to respond when, as in Ebrahimian, it is faced with a state that for reasons not solely related to rights, wishes to uphold a more extensive form of secularism. On the one hand, it has repeatedly recognized that secularism, and measures to defend it, are compatible with the Convention and its values. On the other hand, the list of justifications for restrictions of religious freedom set out in Article 9(2) provide little scope for the kind of prudential, non-rights based considerations that were the historical origins of the secular system (and which, for many continue to provide its most rational defence). ${ }^{37}$

One option, seen in Refah Partisi v Turkey ${ }^{38}$ (a challenge to the dissolution of a party found to be seeking to institute a system based on religious (aw), is to seek to find threats to rights in the violation of secular principles. In Refah the Court found that a system based on Sharia law would violate key rights such as privacy, gender equality and the prohibition on inhuman and degrading treatment, thus allowing it to uphold the dissolution of a party that sought to make such law the basis of the legal system. ${ }^{39}$ However, this involves the Court in the highly problematic endeavor of interpreting religious law and declaring it to be compatible or incompatible with human rights, potentially leaving it open to charges of prejudice, essentialisation of faiths or theological error. Furthermore, this rationale only applies to religions that can be seen as threats to human rights (could a party seeking a Quaker theocracy be dissolved on this basis?) and may encourage the Court to recognize relatively trivial harms as rights violations in order to be able to shoe-horn abstract secularism into the narrow categories of Article 9(2).

Alternatively, the Court could recognize that it must be possible for States to restrict rights in order to serve fundamental constitutional principles which do not themselves necessarily aim to protect fundamental rights. The reasons for this can be varied. Given that religious identity is usually fixed and religious beliefs tend to be comprehensive and to cover ultimate issues such as life and death, religion may be seen as particularly disruptive of political cooperation and stability. ${ }^{40}$ Indeed, the idea of secular politics first arose as a result of the destructiveness of religious contestation for political power in Europe, not out of rights claims ${ }^{41}$ Secularism is not the only principle whose justifications arise from considerations not directly linked to the protection of fundamental rights. Rules preventing the use of French in most Flanders municipalities restrict free expression and cannot be justified as a defence of the individual rights of Dutch speakers as they will remain able to communicate with the municipality in their native language whether French is allowed or not. Rather, they are justified by the need to protect the principle of territoriality in relation to language

\footnotetext{
${ }^{37} \mathrm{n} 32$ above.

${ }^{38} \mathrm{n} 3$ above.

39 ibid at [123].

${ }^{40}$ C. Laborde, Liberalism's Religion (Cambridge MA: Harvard University Press, 2016, forthcoming).

${ }^{41}$ M. Lilla, The Stillborn God: Religion, Politics and the Modern West (New York: Knopf, 2007).
} 
use in Belgium which is necessary for the French and Dutch speakers to remain part of a common State. Similarly, a rule preventing a social welfare clerk in Northern Ireland who treats all in an equally friendly and efficient manner, from wearing a symbol indicating that her allegiances are to the Nationalist or Unionist community is justified not by the rights of those dealing with her but by the need to ensure that both communities in Northern Ireland can share a set of state institutions in the context of a salient and potentially disruptive dispute about the identity of province.

Although critics of the decision in Ebrahimian have claimed that objective evidence of bias is needed ${ }^{42}$ to justify restrictions on the ability of public servants to wear contentious symbols, the common law has generally required evidence not of actual bias but of a reasonable perception of bias. ${ }^{43}$ Harmful consequences can arise from purely symbolic departures from neutrality. To allow a judge to wear the badge of a particular political party while carrying out her functions does damage to valuable principles (such as the separation between the personal identity of the office holder and the office) even if her judgments contain no actual bias. Thus, there may be very good reasons for restricting the right of state employees to express their identity at work that cannot be justified on the basis of a need to avoid concrete harm to the rights of others.

Secularism's commitment to allowing a religiously diverse population to share a single set of political institutions by distinguishing between a religiously-neutral public sphere and a private sphere where religion can flourish, can be compatible with the values of the Convention, but the Court cannot avoid the fact that the text of Article 9 as currently interpreted has a very limited list of reasons other than rights protection that justify restricting religious freedom and therefore struggles to accommodate any but the most minimal secularism. Attempting to obscure this problem by citing concrete, context-specific reasons that religious expression in a particular context may harm rights, and then collapsing this concrete justification into a larger abstract justification based on the need to protect secularism per se, is not satisfactory. The Court will eventually have to grasp the nettle and find scope for non-rights based constitutional principles within Article 9(2).

There is scope witin the case law for it to do so. As Trispiotis points out 'extra-textual principles are familiar from the jurisprudence of the ECtHR. [...] Mutual respect, toleration and solidarity have been repeatedly employed to outline the scope of various rights, including freedom of religion and freedom of assembly and association. ${ }^{, 44}$ He notes how 'peaceful coextistence' between students was cited as reason to restrict religious symbols in universities in Karaduman, 'democratic pluralism' and 'pluralism, tolerance and broadmindedness' could justify state restrictions on 'unwarranted and offensive' attacks on matters regarded as sacred by Muslims in I.A. v Turkey. ${ }^{45}$ As religious competition for access to symbolic or substantive state power can produce particularly intractable conflict, the abstract principle of secularism can readily be seen to serve the goal of 'mutual respect, toleration and solidarity' and 'peaceful coexistence'. In Ebrahimian, however, the Court seems unwilling to admit clearly that it is this aim, rather than weaker, rights-focused concerns, that it is accommodating, and engages in a sleight of hand that collapses discussion of the legitimacy of

\footnotetext{
${ }^{42} \mathrm{n} 20$ above.

${ }^{43}$ Most famously affirmed in $R \vee$ Bow Street Metropolitan Stipendiary Magistrate, ex $p$ Pinochet (No

2) [2000] 1 AC 119.

${ }^{44}$ I. Trispiotis, Freedom of Religion, Equality and Discrimination in the European Convention on Human Rights (Ph.D. Thesis, University College London, 2016) at 168-74.

${ }^{45}$ ibid.
} 
abstract secularism into the discussion of the legitimacy of measures that aim to protect the religious freedom of users of the specific services provided by Ms. Ebrahimian's employer. Its evasiveness in this regard undermines the strength of its judgment.

\section{Proportionality in Cases of Symbolic Harm}

One final issue to note is the degree to which abstract claims raise difficulties in the assessment of proportionality. In previous cases, the Court has seen the severity of the consequence of loss of employment as relevant to the assessment of the proportionality. In Eweida the Court abandoned previous decisions that had held that the right to resign adequately protected freedom of religion and said that the better approach was to weigh the possibility of changing jobs in the balance when considering whether the restriction of the Applicant's religious freedom was proportionate. ${ }^{46}$ In Obst and Schuth the Court found that the difficulty that a church organist would face in finding work outside of the church was a relevant factor in the assessment of the proportionality of the decision of the national courts to uphold his dismissal for having engaged in an extra-marital relationship. ${ }^{47}$ In Ebrahimian, the French authorities had adopted a very wide definition of public servants (the Applicant had been working on a contractual basis for a public hospital). In these circumstances it is likely that the Applicant will be faced with a clash between her religious freedom and a very wide range of jobs (particularly in France where the state sector is a particularly large section of the economy). It is therefore unfortunate that the Court did not address this element of the case in its proportionality assessment.

That is not to say that, had it done so, a different result would inevitably have been reached. It is an unfortunate feature of cases such as this where the aim to avoid symbolic harm clashes with the desire to take a symbolic stand, that the balancing of the two claims is simply impossible. If the point of a state's restriction of religious freedom is to ensure symbolic neutrality of the public service, then any symbolic departure, however slight, will defeat this goal. This 'all or nothing' scenario is like that which applied in the case of Lillian Ladele. She lost her Article 9 challenge to her dismissal for violating her employer's 'Dignity for All' policy by refusing to register same-sex civil partnerships. As the point of the policy in question was to prevent the damage to dignity inherent in acts of discrimination, any accommodation of her discriminatory wish would have entirely defeated the aim of this policy. ${ }^{48}$ One could argue that the restriction in Ladele had a more concrete basis that the more abstract goal of protecting state neutrality cited in Ebrahimian as it aimed to prevent discrimination against same sex couples. ${ }^{49}$ However, once secularism and neutrality are accepted as legitimate aims (something the Court has repeatedly held) then the importance of this distinction disappears as the issue becomes whether the relevant legitimate aim (be it neutrality or non-

\footnotetext{
${ }^{46}$ Eweida and Others v United Kingdom [2013] ECHR 37.

${ }^{47}$ Obst v Germany ECtHR Application no 425/03, 23 September 2010. Schuth v Germany ECtHR Application 1620/03, 23 September 2010.

${ }^{48}$ See R. McCrea 'Religion in the Workplace: Eweida and Others v United Kingdom' (2014) 77 MLR 277.

${ }^{49}$ As noted above, the Court in Ebrahimian also offered concrete reasons based on the impact the wearing of religious symbols by staff may have on vulnerable patients but for the purposes of this article, the most important issue is the degree to which protection of secularism in the abstract was recognized as a legitimate reason to restrict religious expression (rather than relying on instances where secularist principles can be shown to be protecting the rights and freedoms of others).
} 
discrimination) can be achieved by less burdensome means and whether the overall impact on the right in question is disproportionate.

In both Ebrahimian and in Ms. Ladele's case, balancing between the legitimate aim (neutrality/nondiscrimination respectively) and the protected right was impossible within the workplace. Therefore in such cases the proportionality test will have to focus on the question of whether the context in which the restriction on expression takes place is narrow enough to allow adequate scope to express one's beliefs and identity in other contexts. The Strasbourg Court, in dismissing Ms. Ladele's claim, did not provide a detailed proportionality analysis, merely noting that the importance of preventing discrimination meant that the national authorities had not exceeded the margin of appreciation. The national courts were more forthcoming. The UK Court of Appeal noted that the restriction on Ms. Ladele's freedom of religion could be seen as proportionate because it was impossible to accommodate her desire not to serve gay and lesbian couples without undermining the 'nondiscriminatory objectives which [her employer] thought it important to espouse both to their staff and to the wider community ${ }^{\prime 50}$ and because outside of her job, 'she remained free to hold [her] beliefs and free to worship as she wished' ${ }^{.}{ }^{51}$ On this analysis, the possibility of holding and expressing her beliefs out of work rendered the absolute restriction at work proportionate.

If proportionality is to be achieved by delineating the sphere (i.e. the workplace) within which restrictions on expression are to apply, rather than by limiting the degree of restriction within that sphere, the Court's protection of the privacy rights of workers to engage in activities of their choosing out of work will be increasingly important. The Court has been sympathetic to the principle that out of work activities should not be the basis for dismissal in cases such as Redfearn $v U K^{52}$ though in other instances it has upheld such dismissals. ${ }^{53}$ The Court recently adopted a very broad version of the right of employers to fire employees with partly religious tasks for out of work conduct in Fernandez-Martinez v Spain. ${ }^{54}$ Were the kind of duty to discretion outside of work recognized in that case applied to public servants, then the extent of the restriction on religious freedom of those working in the public service would almost certainly become excessive and disproportionate. The legitimacy of the secular system (and its claim to restrict religious freedom in a proportionate way) very much depends on vigilant policing of the boundary between state and non-state, and public and private contexts.

\section{Conclusion}

Religion is both a series of beliefs to be chosen or rejected and a form of personal identity that is lived as a communal matter and is, in reality, rarely changed. Defining religion as a matter of choice and belief will often lead to results which are the direct opposite of those which would arise from treating it as an immutable form of personal identity. It is therefore difficult for the ECtHR to come

\footnotetext{
${ }^{50}$ Ladele v London Borough of Islington [2009] EWCA Civ 1357 at [49].

${ }^{51}$ ibid. at [50].

52 [2012] ECHR 1878. Here the Court found a violation in respect termination of the employment of a bus driver for active membership in an extremist political party.

${ }^{53}$ See Pay v UK [2009] IRLR 139 where the Court found no violation due to the failure of the applicant to take steps to ensure that no link could be made between his involvement in sadomasochistic sexual activities and his work as a probation officer. See V. Mantouvalou 'Human Rights and Unfair Dismissal: Private Acts in Public Spaces (2008) 71 MLR 912.

${ }^{54}$ [2014] ECHR 886.
} 
up with solutions that give significant weight to all of the elements that make up religion. French rules on the absence of religious symbols from state contexts treat religion as a form of belief and religious symbols as forms of ideological expression that ought not to appear within state contexts. In other contexts, such as the prohibition on discrimination in service provision, religion is treated by the law as something more akin to a fundamental personal characteristic such as gender. ${ }^{55}$ Treating religion in different ways in different contexts is not necessarily wrong. There is a range of factors that affect how religion should be regarded in any situation. When assessing anti-proselytism laws it makes sense for a liberal state to view religion as a matter of belief and choice. When dealing with the right to receive services in a private shop, it may make more sense to view it as a form of personal identity. In other cases, such as the scenario in Ebrahimian, it is less clear which approach should be taken. There are good reasons for either option.

As long as there were reasonable grounds for accepting the French authorities' characterisation of religious expression in the circumstances of the case, the Strasbourg Court was not likely to intervene. Indeed, even those who were critical of the decision in Ebrahimian conceded that they were not surprised by the result. ${ }^{56}$ The Court has permitted states to view religious expression in state institutions as ideological expression in an inappropriate context. The ECtHR had previously repeatedly endorsed secularism as consistent with Convention values and had previously upheld the strict application of secularist principles in the educational context. Extending this toleration of the rigorous application of secularist principles to the public service as a whole was therefore not unexpected.

Despite frequent allegations (including in the dissenting opinions in Ebrahimian) that the Court has displayed bias in favour of Christian symbols and against Islamic ones, the approach of the ECtHR has actually been consistent. Rulings, including that in Ebrahimian, have consistently stressed that there are deep reasonable differences on how best to arrange the relationship between religion and state in Europe, and the Court has adopted a consistently 'hands-off' approach. It has intervened only where arrangements are notably oppressive and has concluded that a broad range of diverse arrangements in this area are compatible with the ECHR. Thus, it has found that there are sufficiently good reasons supporting a member state decision to restrict the presence of religious symbols in state schools ${ }^{57}$ but that it is also not beyond the range of reasonable options for states to maintain the traditional presence of some religious symbols in classrooms provided that the overall effect is not oppressive. ${ }^{58}$ Certainly, a hands-off approach is likely to be disadvantageous for minority religions but the overall approach is clear and consistent: deference to states in the context of abiding, salient and deep reasonable differences.

Though the result was consistent with previous caselaw, the Court's reasoning in this case was unfortunately unclear. The well-argued points made by Judge O'Leary highlight the tension between

\footnotetext{
${ }^{55}$ For a discussion of the difference between religious freedom as a choice right and the idea of religion as a form of identity that underpins the prohibition of discrimination and grounds of religion see R. McCrea 'Singing from the Same Hymn-Sheet? What the Differences between the Strasbourg and Luxembourg Courts Tell Us about Religious Freedom, Non-Discrimination and the Secular State' (2016) Oxford Journal of Law and Religion (forthcoming).

${ }^{56} \mathrm{n} 20$ above.

${ }^{57} \mathrm{n} 2$ above, Dahlab v Switzerland.

${ }^{58} \mathrm{n} 35$ above.
} 
the relatively narrow and exhaustive grounds listed in Article 9(2) and the repeated statement by the Court that the abstract constitutional principle of secularism is in line with values of the Convention. This is not to suggest that the Court should restrict Member Stats to the narrow and limited form of secularism that can be justified by the need to defend fundamental rights. Such an option involves an a-historical neglect of the significant non-rights based reasons for secularism and would provoke a clash between the Convention and the deepest constitutional principles of at least one member state, principles which have been developing following an intense process of democratic debate in the state in question.

However, the Court must be clear about what it is doing. If it is to endorse more abstract secularism, it should own up to the fact that such endorsement involves factors beyond the protection of the rights and freedoms of others. This need not involve a radical break with its caselaw. The Court has found room in its jurisprudence to uphold prudential arrangements that seek to defuse abiding and salient cleavages within political communities such as those relating to language in Belgium ${ }^{59}$ and religion can be a source of division that is deeper, more durable and more intense than language. In addition, as Trispiotis shows, extra-textual reasons have featured prominently in the Court's caselaw in other religion-related cases.

This more expansive approach is inevitable and desirable. Rights do not provide a full account of the key elements of our political and social arrangements, particularly in relation to religion and its relationship to the state. ${ }^{60}$ That said, it must be acknowledged that a more expansive approach to justifications for restricting religious freedom will bring a significant danger that a fundamental right will be increasingly subject to majoritarian whims. The Court will have to be vigilant to ensure that when a state invokes extra-textual principles, such principles are in fact in line with underlying Convention values and that they are not being manipulated as a vehicle to promote majoritarian prejudices or to exercise domination over minorities. Judge O'Leary is right that allowing abstract principles to qualify rights brings significant dangers of restriction of fundamental rights on vague and potentially limitless grounds. Although matters of constitutional and political theory are difficult for the Strasbourg Court to deal with, it may be unavoidable for the Court to make the normative basis of its approach more clear. Neutrality cannot be a goal in itself and if it is to be invoked to restrict fundamental rights, the Court will have to specify what goals and values it sees such neutrality as protecting. Finally, in relation to secularism more specifically, the Court must be rigorous in ensuring that, as it did in Ahmet Arslan, ${ }^{61}$ secularist reasons are used only to justify in restrictions on religious expression the state sphere and that they are not permitted to provide the basis for restrictions of the right to live out one's religious identity in the non-state arena.

\footnotetext{
${ }^{59}$ Belgian Linguistics Case [1968] ECHR 3.

${ }^{60}$ See $\mathrm{n} 32$ above.

${ }^{61} \mathrm{n} 16$ above.
} 